Discussion Paper Series A No.557

\title{
Causes of Corruption in Russia: A Disaggregated Analysis
}

\author{
Veronika Belousova \\ (National Research University Higher School of Economics, Russia) \\ Rajeev K. Goel \\ (Illinois State University, USA) \\ and \\ Iikka Korhonen \\ (Previous Visiting Professor, Institute of Economic Research, \\ Hitotsubashi University and Bank of Finland, Finland)
}

December 2011

Institute of Economic Research Hitotsubashi University

Kunitachi, Tokyo, 186-8603 Japan 


\title{
Causes of Corruption in Russia: A Disaggregated Analysis
}

\author{
Veronika Belousova \\ National Research University Higher School of Economics, Russia \\ Rajeev K. Goel \\ Illinois State University, USA \\ Iikka Korhonen* \\ Bank of Finland, Finland
}

Keywords: corruption perceptions, corruption incidence, Russia, government, competition

JEL classification: K42; O42; P37

September 2011

\begin{abstract}
$\underline{\text { ABSTRACT }}$
This paper examines determinants of corruption across Russian regions. Key contributions include: (i) a formal study of economic corruption determinants across Russian regions; (ii) comparisons of determinants of perceived corruption versus those of actual corruption; and (iii) studying the influence of market competition and other factors on corruption. The results show that economic prosperity, population, market competition and urbanization are significant determinants of Russian corruption. The use of alternative corruption measures reveals that economic prosperity and population have a largely similar impact on corruption perceptions and corruption incidence. However, there are significant differences in the effects of competition and urbanization.
\end{abstract}

Corresponding author: Bank of Finland Institute for Economies in Transition (BOFIT), PO Box 160, 00101 Helsinki, Finland. Phone +358 10 8311, E-mail: Iikka.korhonen@bof.fi. Iikka Korhonen wishes to thank Hitotsubashi University for its hospitality while he was working on this research project. 


\section{Causes of Corruption in Russia: A Disaggregated Analysis}

\section{Introduction and motivation}

This research uses regional data to formally examine the economic causes of corruption across regions of the Russian Federation. Besides providing unique insights into factors determining corruption, this paper contributes to the broader literature on countryspecific corruption studies and provides useful policy inputs. While there are numerous studies examining various aspects of cross-national corruption, related investigations analysing details of corruption in individual countries are few, due primarily to a lack of adequate data on the extent of corrupt activity across regions. In addition, we evaluate causes of both corruption perception and actual corruption incidence, which is still relatively rare in the literature.

In international comparisons of corruption perceptions, Russia usually fares relatively badly. For example, in 2010, Transparency International, the corruption watchdog organization, ranked Russia 154th out of 178 countries in terms of corruption perceptions (Transparency International, 2010). While one can debate whether Russia is really more corrupt than, say, Haiti, it is clear that corruption is a serious problem in Russia, ranging from petty corruption to high-level corruption involving e.g. legislators and senior civil servants. This makes studying causes and covariates of corruption all the more important for Russia. It is likely that corruption significantly influences economic decisions by both households and companies. For example, a majority of 
Russians seem to treat law enforcement officials with apprehension, which has an obvious effect on willingness to obey laws and on contract enforcement. ${ }^{1}$

Russia is a large, geographically and ethnically diverse country. Hence, it is natural to assume that corruption also varies between regions. Since 2008, the Russian Federation has consisted of 83 federal subjects, while before 2008 there were 89 regions. There are all-in-all six different categories of federal subject ${ }^{2}$, including two federal cities: Moscow and St Petersburg. Regions differ in geographical size, population, degree of urbanization and economic structure. We are thus well positioned to assess what kinds of factors are associated with corruption in Russian regions.

Country-specific corruption studies are generally hampered by the availability of adequate data, and Russia is no exception. While a handful of papers examine corruption in Russia from various points of view (for more details see Guriev (2007)), there is a paucity of papers examining the regional variation in corruption in Russia. Regarding the small amount of literature formally studying the determinants of Russian corruption, Dininio and Orttung (2005) and Sharafutdinova (2010) use different aspects of similar corruption data to us to test primarily political causes of corruption. They consistently find that a higher per capita income level decreases corruption. In addition, Dininio and Orttung (2005) argue that the effect of the size of the bureaucracy is sensitive to whether population effects are accounted for or not. Since the largest number of Russian bureaucrats can be found in Moscow, followed by St Petersburg, this

\footnotetext{
${ }^{1}$ Troika Dialog (2011) reports a Levada Center opinion poll in which $67 \%$ of respondents treat law enforcement officials 'probably' or 'definitely' with apprehension. Only 5\% 'definitely' trust them.

${ }^{2}$ Russia has 21 republics, 9 krais ('territories'), 46 oblasts ('provinces'), one autonomous oblast ('The Jewish Autonomous Oblast' in the Russian Far East), 4 autonomous okrugs ('autonomous districts') and two federal cities. For the purpose of this study, the administrative differences between region types do not matter.
} 
indicates that the two metropolises are likely to lie behind this sensitivity. No other (mainly political) variable is statistically significant in explaining the amount of corruption.

In another study, Demidov (2005) looks into the effectiveness of the President's special envoys to federal okrugs ${ }^{3}$ in tackling corruption. In principle, special envoys could be effective e.g. in tackling corruption among the governors of different regions. However, Demidov's view is that they certainly had no positive influence on corruption, and, in some cases, the envoys and their staff seem to have increased the level of corruption. Further, Mokhtari and Grafova (2007) develop a model where tax inspectors are potential bribe-takers, and therefore an increase in the number of inspectors can actually decrease tax revenue, ceteris paribus. In their empirical study, too, they find that the number of tax inspectors is negatively related to per capita tax collection. The authors conclude that bribe-taking in the tax administration explains the result. Our contribution is quite different from Mokhtari and Grafova (2007). While their theoretical model was concerned with bribe-taking, their empirical model did not include any variables directly dealing with corruption. Instead they relied on indirect inference regarding the level of corruption in Russia's tax administration.

In actual fact, these studies do not formally examine the distinction between perceived and actual corruption. We, in contrast, are able to look directly at the correlation of corruption incidence and perceptions with respect to a variety of economic and social variables. We find that higher income levels tend to decrease both the perception of corruption and its incidence. This result holds for several different

\footnotetext{
${ }^{3}$ To ease administration of the Federation, President Putin divided the country initially into seven federal okrugs. Later, an eighth okrug was added.
} 
measures of income. In this respect our results mirror those obtained in cross-country studies (Serra (2006)), among others. Higher population seems to increase both corruption incidence and perception, although the effect is non-linear. It is interesting that variables relating to the scope of government activities at the regional level do not have statistically significant effects on corruption. Another noteworthy finding is that in Moscow and St Petersburg, the two main seats of political and economic power in Russia, the perception of corruption is lower, while the actual incidence of corruption is higher than elsewhere. It may be that wealthier people in the two largest cities do not perceive corruption as one of their key problems, while e.g. businesses are required to pay more bribes in these two cities than elsewhere. Urbanization reduces corruption perceptions, but not incidence. People in larger cities may find it harder to track the actions of other citizens as well as civil servants. Finally, the effects of competition in the marketplace are different on perceived versus actual corruption. Having more companies per capita increases corruption perception, perhaps because people perceive companies to be competing for favours vis-à-vis the public sector. However, this effect does not show up in the data on the incidence of actual corruption.

\section{Model, estimation and data}

\subsection{Theoretical background}

The theory relating to the causes of corruption is tied to the broader literature on the causes of criminal activity, where bribe-takers and bribe-givers weigh the relative costs and benefits of their actions (Becker, 1968). For instance, increases in general economic prosperity raise the potential costs of illegal acts via strengthened enforcement and by 
raising the costs of apprehension and punishment for perpetrators. Building on this general theme, other scholars, notably Rose-Ackerman (1999) and Shleifer and Vishny (1993), have framed theories specific to corrupt activity. In this context, the role of the government, including its ability to generate red tape and disburse favours out of turn, is a crucial determinant of corrupt activity (Guriev (2004)). Government agencies often hold monopoly powers on disbursement of contracts, which presents unique opportunities for rent-seeking. Competition among favour-seekers (including the public as well as large and small businesses), on the other hand, induces some with resources to offer higher bribes. Further, even when some government enterprises are privatized (as has been the case especially in transition economies, including Russia), this creates additional avenues for generating rent (Kaufmann and Siegelbaum (1997), Varese (1997)). Finally, anti-corruption initiatives are likely to be tied to the economic status of regions (Boerner and Hainz (2009)). In the empirical model below, we take account of the role of the government in terms of its possible impact on corruption.

Empirical studies of corruption have mainly used cross-national indices of corruption, in recent years examining numerous determinants to such an extent that this line of inquiry seems to have reached saturation point (see Aidt (2003), Jain (2001), Lambsdorff (2006), Pellegrini and Gerlagh (2008), Serra (2006) for reviews of the extant literature). Country-specific studies are quite limited, primarily due to a paucity of acceptable corruption data (exceptions include Glaeser and Saks (2006) and Goel and Nelson (2011) for the United States, and Dong and Torgler (2010) for China). The present research adds to the literature by examining causes of corruption across Russian regions. There have only been a few formal studies of corruption in Russia, ${ }^{4}$ although

\footnotetext{
${ }^{4}$ See introduction in section 1 above for some exceptions.
} 
the country has some unique attributes that could crucially impact the level of corrupt activity, notably its sheer size and the transition to a market economy. ${ }^{5}$

\subsection{Estimation model}

Following the above discussion, and based on the overall literature on the causes of corruption (see Aidt (2003), Jain (2001), Lambsdorff (2006), Serra (2006), Svensson (2005), Treisman (2000)), our general estimated equation to explain the causes of corruption across Russian regions takes the following general form (with subscript $i$ denoting a Russian region):

Corruption $_{i j}=f\left(\right.$ Economic stature $_{i k}$, Government role $_{i m}$, Population $i$, Competition $_{i}$, Privatization $_{i}$, Urban $_{i n}$, Unemployment $_{i}$ )

$$
\begin{aligned}
& i=1, \ldots, 40 \\
& j=\text { CORRperc }, \text { CORRamt } \\
& k=\text { GRPpc, INCpc } \\
& m=\text { GOVTemp, GOVTtran } \\
& n=\text { Urbanization, DUMmspt }
\end{aligned}
$$

The dependent variable is alternately measured as an index of corruption perceptions (CORRperc) and as an index of corruption incidence (CORRamt). Both indices range from zero to one, with one denoting the highest level of corruption. ${ }^{6}$ While appropriate

\footnotetext{
${ }^{5}$ See Levin and Satarov (2000) for an illuminating general discussion. See also Cheloukhine and King (2007), Osipian (2010) and Safavian et al. (2001).

${ }^{6}$ In the formal estimation, we take the natural logarithms of both CORRperc and CORRamt to unbind them. This transformation, however, results in the loss of one observation, as a natural logarithm is undefined at zero.
} 
caution should be used in interpreting the indices, the mean on CORRperc in the sample is greater than that on CORRamt $\rightarrow 0.59$ versus 0.44 . Further, the correlation between the two corruption measures is a modest 0.31 (see Table 3 ). A list of regions included in the sample is provided in the Appendix.

This alternative treatment of the dependent variable provides a useful robustness check, especially given some criticisms in the literature regarding the shortcomings of corruption perception indices (Olken (2009), Sampford et al. (2006)). Further, the determinants of corruption have been shown to be somewhat sensitive to the measure of corruption employed. For example, see Goel and Nelson (2011) for evidence related to the United States and Treisman (2007) for cross-national evidence. ${ }^{7}$

In line with the literature that takes economic prosperity to be a strong determinant of corruption (see Gundlach and Paldam (2009), Serra (2006); also Bardhan (1997) for a broader discussion), the economic status of a region is included by using two different measures: (i) gross regional product per capita (GRPpc); and (ii) regional income per capita $(I N C p c)$. The use of different prosperity measures should provide a useful test of the validity of the findings. In our sample, the correlation between GRPpc and INCPc is 0.84 (Table 3). The overall idea is that improvement in economic well-being reduces corruption, either by increasing governmental resources devoted to anti-corruption efforts or by increasing the opportunity costs for illegal acts by both bribe-takers and bribe-givers (Boerner and Hainz (2009)).

The role of government is crucial in both generating and combating rentseeking activities (see Rose-Ackerman (1999), Shleifer and Vishny (1993) for general

\footnotetext{
${ }^{7}$ Even in this broader literature, however, there is no evidence of consistent and comparable cross-national indices of either corruption perceptions or corruption incidence.
} 
discussion, and Levin and Satarov (2000) for related discussion specific to Russia). Government employment (GOVTemp) can proxy for the size of bureaucracy, ${ }^{8}$ although some public employees may be involved in fighting corruption (e.g., judicial and police employment). Further, governments routinely make transfer payments (grants), which provides opportunities for rent-seeking for officials in charge of disbursements. We account for this aspect by including transfers from the federal government to regional governments (GOVTtran).

Population $(P O P)$ is included to account for the physical size of regions and to capture the competition for favours (see Fisman and Gatti (2002) and Glaeser and Saks (2006) for a similar consideration in the case of the United States). Other things being the same, greater population would increase corrupt activity, although there might be some nonlinearities in the relation between corruption and population. While population captures general competition for favours, we include the number of enterprises per capita (Compete) as a measure of market competition and to capture competition for favours from businesses. The comparison of relative effects of general favours sought by the population versus those by businesses is a novel angle studied in the literature. Privatization creates opportunities for rent-generation through the sale of favours, although it is possible that, over time, corruption might even be greater in the absence of privatization (Kaufmann and Siegelbaum (1997)). The link between privatization in transition economies and the level of corrupt activity has been recognized by several scholars (see Kaufmann and Siegelbaum (1997) and Varese (1997) for examples). It would be interesting to study whether privatization matters in terms of its impact on corruption after the heavy phase of privatization in the initial transition years ended. We

\footnotetext{
${ }^{8}$ Doninio and Orttung (2005) alternatively measure the size of bureaucracy by the (nonnormalized) number of bureaucrats.
} 
use the number of public enterprises privatized per capita (Privatize) in each region to capture the influence on corruption perceptions and incidence. Besides the comparative effects on perceptions versus incidence, the use of hard privatization data (as opposed to indices of privatization) can be seen as a contribution to the broader corruption literature.

Competition for favours and risk of exposure for corrupt acts might also be greater in urban areas. The degree of urbanization $(U R B A N)$ is accordingly included in the estimations (see Glaeser and Saks (2006)).

Further, two Russian regions, Moscow and St Petersburg, are large urban areas, as well as the main seats of political and economic power. Other things being the same, there is likely to be greater competition for favours and greater government disbursements in these regions. To take this into consideration, we include a dummy variable, DUMmspt, that takes the value one if the region is Moscow or St Petersburg and zero elsewhere. Finally, the impatience of bribe-givers to offer bribes might be greater in periods of high unemployment $(U N)$, as there are more unemployed vying for jobs and some might be willing to offer bribes to secure government jobs and contracts.

\subsection{Data}

The data on corruption are from the Russian arm of Transparency International. While these data come from a reputable organization and provide a consistent measure of corrupt activity, they are not without some shortcomings - the main ones being availability for one year only (2002) and the limitation to only forty regions (out of a total of 89, although the most important ones are included - see Appendix for a list of included regions). However, the data are quite representative of geographical, industrial and ethnic diversity across Russia. For more detailed information concerning the data, 
see Transparency International (2002). In the absence of a better measure of corruption, and to provide formal insights into causes of corruption in Russia using this unique insight, we limit the study to 2002 and to forty regions. One virtue of using the 2002 data is that this period is unlikely to be picking up disproportionately high corruption associated with nascent institutions and large-scale privatization in the initial transition years (see Andvig (2006), Levin and Satarov (2000), Osipian (2010)).

We utilize both corruption perception and incidence data, as this is more likely to give a more nuanced picture of the situation. The underlying data is collected from surveys of both individuals and small and medium-sized enterprises. Corruption perception means correspondents' general perception of corruption (everyday, related to different levels of administration etc.) in their region. The corruption incidence index is based on data from questions relating to the frequency and amounts of bribe-giving the respondents themselves had been associated with.

The data for the other variables come mostly from the Russian Federal Statistical Service (www.gks.ru). Details about the variables used, summary statistics and data sources are provided in Table 1, while Table 3 provides pair-wise correlations.

\section{Results}

All cross-sectional estimations were conducted using the STATA software package, with OLS used as the estimation technique. ${ }^{9}$ The estimation results are reported in Table 2. Panels A and B, respectively, in Table 2 report results with alternative measures of

\footnotetext{
${ }^{9}$ The relatively modest sample size and its cross-sectional dimension place some limitations on the scope of the analysis and the nature of the estimation methodology employed.
} 
corruption as the dependent variable - corruption perceptions (CORRperc) and corruption incidence (CORRamt). The different models in Table 2 have a reasonable fit, especially given the relatively small size of the sample.

As a general test of specification, we performed a RESET test. This generally showed an absence of significant specification error in all cases - i.e. the resulting chisquared statistic was statistically insignificant at the five per cent level in all instances. The following aspects are noteworthy across determinants of corruption perceptions and incidence, respectively.

\subsection{Determinants of corruption perceptions}

- Greater economic prosperity reduces corruption perceptions. This finding is robust across the two measures: GRPpc and $I N C p c .{ }^{10}$ It is likely the case that more prosperous regions have greater anti-corruption measures and relatively prosperous individuals are dissuaded from engaging in illegal corrupt activities. $^{11}$

- The role of government, measured alternately by government employment (GOVTemp) or via government transfers (GOVTtrans), does not appreciably affect corruption perceptions. $^{12}$

- Greater population density $(P O P)$, signifying competition for favours among bribe-givers, increases corruption perceptions, albeit the relation appears to be

\footnotetext{
${ }^{10}$ Potential reverse causality from corruption to prosperity is somewhat mitigated by the crosssectional nature of the analysis. Recent research has, in any case, shown that the main direction of causality runs from prosperity to corruption (Gundlach and Paldam (2009)).

${ }^{11}$ See Gundlach and Paldam (2009) for support for this finding in a cross-national context, and Sharafutdinova (2010) for Russia.

${ }^{12}$ It is possible, however, that inclusion of governmental data at a finer level of detail could provide greater insights, as has been seen in regards to other countries. See, for example, Fisman and Gatti (2002).
} 
nonlinear. Nonlinearities between corruption and its determinants are largely ignored in related studies (Serra (2006)).

- Greater competition between firms (Compete), on the other hand, strongly contributes to corruption perceptions in all instances. Bribe-giving by firms can be perceived to be widespread, both among the general population and vis-à-vis other companies.

- Greater privatization does not affect corruption perceptions. The resulting coefficient is statistically insignificant. It is likely the case that after the initial phase of privatization, further privatization was more sporadic.

- The unemployment rate $(U N)$ does not show appreciable impacts on the level of corrupt activity (see Sharafutdinova (2010) for similar findings).

- Greater urbanization $(U R B A N)$ lowers corruption perceptions. The intuition behind this finding is that greater urbanization is acting as a deterrent, with both bribe-takers and bribe-givers being somewhat dissuaded by the relatively greater risk of exposure in urban areas. There is also generally greater media attention on corrupt activities in urban areas.

- Consideration of another dimension of urbanization by separately focusing on the largest metropolitan areas produces different findings. The dummy variable identifying the two large metropolitan areas of Moscow and St Petersburg (DUMmspt) is negative and significant in all instances. Controlling for various factors, corruption perceptions were lower in the largest urban regions. Interestingly, this also holds when the degree of urbanization is controlled for (Model 5A).

We turn next to examining the determinants of actual corruption. 


\subsection{Determinants of corruption incidence}

- As before, greater GRPpc and INCpc lower corruption incidence. The findings with regard to the negative effect of $G R P p c$ on corruption incidence support earlier literature on Russian corruption (Dininio and Orttung (2005)) as well as the broader literature on corruption determinants (see Gundlach and Paldam (2009); and Lambsdorff (2006) and Serra (2006) for literature reviews). The significance of different economic prosperity measures in reducing corruption perceptions as well as corruption incidence is noteworthy, especially given the modest correlation between the two corruption measures (Table 3).

- The effects of the two government variables (GOVTemp and GOVTtran), and of those of urbanization and unemployment, are statistically insignificant on corruption incidence as well as corruption perceptions.

- Regional population $(P O P)$ again shows nonlinearities in terms of its effects on corruption, although the quadratic term is now significant in one of the two cases (Model 2B with INCpc denoting economic prosperity).

- A more striking contrast across corruption causes emerges with regard to Compete. Greater market competition does not significantly affect corruption incidence. Thus, while competing firms are perceived to seek favours via bribery, these efforts are not registering in terms of increases in actual corruption.

- Privatization, like its effect on corruption perceptions, fails to show up as significant in corruption incidence. From a political perspective, additional privatization in the decade following the breakup of the Soviet Union seems relatively insignificant, at least from a corruption viewpoint. 
- Corruption incidence is found to be greater in the Moscow and St Petersburg regions, ceteris paribus, especially in the models where population effects are directly accounted for (Models 1B and 2B). This result is consistent with the notion that there is greater disbursement of favours in large government seats, trade centres and major ports (see Goel and Nelson (2011)). Again, it is noteworthy that in the two largest cities, corruption perception is lower than incidence.

Besides the differences across the determinants of perceived and actual corruption noted above, several other points seem significant. Firstly, in terms of magnitude, increases in economic prosperity have a greater (negative) effect on corruption incidence than on corruption perceptions. This is true for both measures of prosperity employed and is consistent with intuition. Secondly, the effects of government employment are insignificant. (Findings for corruption across US states in this regard are mixed, see e.g. Glaeser and Saks (2006) and Goel and Nelson (2011).) Thirdly, the effects for urbanization are found to be negative on corruption perceptions, but not on incidence for Russia. (The evidence for the US is mixed in this regard. Some have found the effects of urbanization to be significant (Goel and Nelson (2011), while others have not (Glaeser and Saks (2006).) Fourthly, employing 'hard' data on the number of enterprises privatized, we find that privatization has no impact on actual or perceived corruption. Fifthly, there is a marked difference in the impact of the two largest metropolitan regions in terms of their impacts on perceptions and incidence. The two main seats of power have higher incidence of corruption, while corruption perceptions are lower. Finally, greater market competition between firms increased corruption perceptions but not incidence. 


\section{Conclusions}

This paper contributes to the literature on country-specific studies of corruption by examining economic causes of corruption across Russian regions. Specific contributions include: (i) formal study of corruption causes across Russian regions; (ii) comparisons of determinants of perceived corruption and those of actual corruption; and (iii) examining the influence of the size of the enterprise sector on corruption.

Our results show that economic prosperity, population, urbanization, market competition as well as large metropolitan regions are significant determinants of Russian corruption, with often significant variations in explaining perceived versus actual corruption. The negative effect of economic prosperity supports the larger corruption determinants literature (see Gundlach and Paldam (2009) and Serra (2006), and the effect on corruption incidence supports earlier findings for Russia (Dininio and Orttung (2005). In terms of magnitude, increases in economic prosperity (negatively) impact corruption incidence more than they do corruption perceptions. On the other hand, the effects of government employment and transfers as well as unemployment are statistically insignificant. Related findings for these factors from other countries are mixed (Fisman and Gatti (2002), Glaeser and Saks (2006), Goel and Nelson (2011)). Greater market competition increases corruption perceptions, but not incidence. This finding can be seen as tying into the cross-national literature that has found greater economic freedom lowers corruption (Goel and Nelson (2005)). However, unlike the cross-national literature, our measure of economic freedom is based on hard data (i.e. number of enterprises) and we find that competition in fact adds to Russian corruption perceptions. 
The use of alternative measures of corruption provides some interesting insights. While economic prosperity and population have a similar impact on both corruption perceptions and corruption incidence, there is a stark difference with regard to the main metropolitan areas of Moscow and St Petersburg, and with respect to number of enterprises. Unlike corruption perceptions (which are consistently lower across all models), the incidence of corruption is shown to be greater in the two main metropolitan areas and the resulting effect is significant in two instances. Further, it seems that a vibrant economy and economic freedoms, as measured by the number of per capita enterprises, lead to higher corruption perceptions, i.e. people feel something illegal must be taking place as the number of enterprises grows. However, the actual incidence of corruption does not increase.

From a policy perspective, we can make a few recommendations for corruption control across Russian regions. Firstly, as regions attain greater economic prosperity, the level of corrupt activity (both perceived and actual) will tend to decline. Hence policies supporting economic development are recommended for corruption control as well. Secondly, policies to combat corruption in large areas, denoted by large population, might need to be different. Thirdly, while policymakers strive to get a better handle on how corruption is measured (see Olken (2009), Sampford et al. (2006) for related discussion), they should be careful to distinguish between perceived and actual corruption, as evidenced by our results for the number of enterprises. Perceptions about corruption might be quite different from reality also with regard to the two main metropolitan areas. However, the size of the public sector does not seem to appreciably contribute to corruption. 


\section{References}

Aidt, T.S., 'Economic Analysis of Corruption: A Survey', Economic Journal 113, 2003, 632-652.

Andvig, J., 'Corruption in China and Russia Compared: Different Legacies of Central Planning', in S. Rose-Ackerman (ed.), International Handbook on the Economics of Corruption, Cheltenham, UK: Edward Elgar, 2006, 278-322.

Bardhan, P., 'Corruption and Development: A Review of Issues', Journal of Economic Literature 35, 1997, 1320-1346.

Becker, G.S., 'Crime and Punishment: An Economic Approach', Journal of Political Economy 76, 1968, 169-217.

Boerner, K. and C. Hainz, 'The Political Economy of Corruption and the Role of Economic Opportunities', Economics of Transition 17, 2009, 213-240.

Cheloukhine, S. and J. King, 'Corruption Networks as a Sphere of Investment Activities in Modern Russia', Communist and Post-Communist Studies 40, 2007, 107-122.

Demidov, B., 'Corruption in Russia, 2000-2003: The Role of the Federal Okrugs and Presidential Envoys', in P. Reddaway and R.W. Orttung (eds.), The Dynamics of Russian Politics - Putin's Reform of Federal-Regional Relations, Volume II, Lanham: Rowman \& Littlefield Publishers, 2005.

Dininio, P. and R. Orttung, 'Explaining Patterns of Corruption in the Russian Regions', World Politics 57, 2005, 500-529.

Dong, B. and B. Torgler, The Causes of Corruption: Evidence from China, FEEM working paper \#72, 2010, www.ssrn.com.

Fisman, R. and R. Gatti, 'Decentralization and Corruption: Evidence from U.S. Federal Transfer Program', Public Choice 113, 2002, 25-35.

Glaeser, E.L. and R.E. Saks, 'Corruption in America', Journal of Public Economics 90, 2006, 1053-1072.

Goel, R.K. and M.A. Nelson, 'Measures of Corruption and Determinants of U.S. Corruption', Economics of Governance 12, 2011, 155-176.

Goel, R.K. and M.A. Nelson, 'Economic Freedom versus Political Freedom: CrossCountry Influences on Corruption', Australian Economic Papers 44, 2005, 121-133.

Gundlach, E. and M. Paldam, 'The Transition of Corruption: From Poverty to Honesty', Economics Letters 103, 2009, 146-148.

Guriev, S., 'Red Tape and Corruption', Journal of Development Economics 73, 2004, 489-504. 
Guriev, S., 'Corruption in Russia: What Do We Know and What Can We Do?' Voprosy Ekonomiki, 2007, 11-18 (in Russian).

Jain, A.K., 'Corruption: A Review', Journal of Economic Surveys 15, 2001, 71-121.

Lambsdorff, J.G., 'Causes and Consequences of Corruption: What do we Know from a Cross-Section of Countries?' in S. Rose-Ackerman (ed.), International Handbook on the Economics of Corruption, Cheltenham, UK: Edward Elgar, 2006, 3-51.

Levin, M. and G. Satarov, 'Corruption and Institutions in Russia', European Journal of Political Economy 16, 2000, 113-132.

Mokhtari, M. and I. Grafova, 'Corruption: Theory and Evidence from the Russian Federation', Economic Systems 31, 2007, 412-422.

Olken, B.A., 'Corruption Perceptions vs Corruption Reality', Journal of Public Economics 93, 2009, 950-964.

Osipian, A.L., 'Corrupt Organizational Hierarchies in the Former Soviet Bloc', Transition Studies Review 17, 2010, 822-836.

Pellegrini, L. and R. Gerlagh, 'Causes of Corruption: A Survey of Cross-Country Analyses and Extended Results', Economics of Governance 9, 2008, 245-263.

Rose-Ackerman, S., Corruption and Government, Cambridge: Cambridge University Press, 1999.

Safavian, M.S., D.H. Graham and C. Gonzalez-Vega, 'Corruption and Microenterprises in Russia', World Development 29, 2001, 1215-1224.

Sampford, C, A. Shacklock, C. Connors and F. Galtung, Measuring Corruption, Aldershot: Ashgate, 2006.

Serra, D., 'Empirical Determinants of Corruption: A Sensitivity Analysis', Public Choice 126, 2006, 225-256.

Sharafutdinova, G., 'What Explains Corruption Perceptions? The Dark Side of Political Competition in Russian Regions', Comparative Politics 42, 2010, 147-166.

Shleifer, A. and R.W. Vishny, 'Corruption', Quarterly Journal of Economics 108, 1993, 599-617.

Svensson, J., 'Eight Questions about Corruption', Journal of Economic Perspectives 19, 2005, 19-42.

Transparency International, Regional Corruption Indices 2002, transparency.org.ru/proj_index.asp, Moscow: Transparency International, 2002.

Transparency International, Corruption Perceptions Index 2010, Berlin: Transparency International, 2010. 
Treisman, D., 'The Causes of Corruption: A Cross-National Study', Journal of Public Economics 76, 2000, 399-458.

Treisman, D., 'What Have We Learned About the Causes of Corruption from Ten Years of Cross-National Empirical Research?' Annual Review of Political Science 10, 2007, 211-244.

Troika Dialog, Russia Economic Monthly March 2011, Moscow: Troika Dialog, 2011. 


\begin{tabular}{|c|c|c|}
\hline Variable & $\begin{array}{l}\text { Definition } \\
\text { (mean; standard deviation) }\end{array}$ & Source \\
\hline CORRperc & $\begin{array}{l}\text { Index of corruption perceptions, higher values } \\
\text { greater corruption, range: } 0-1 ; 2002,(0.587 \text {; } \\
0.208)\end{array}$ & $\begin{array}{l}\text { Center Transparency International } \\
\text { - Russia (transparency.org.ru) }\end{array}$ \\
\hline CORRamt & $\begin{array}{l}\text { Amount of corruption, higher values greater } \\
\text { corruption, range } 0-1 ; 2002,(0.443 ; 0.297)\end{array}$ & $\begin{array}{l}\text { Center Transparency International } \\
\text { - Russia (transparency.org.ru) }\end{array}$ \\
\hline GRPpc & $\begin{array}{l}\text { Gross revenue product per capita, } 2002 \text {, current } \\
\text { prices, roubles, }(56,417.860 ; 42,610.290)\end{array}$ & $\begin{array}{l}\text { Federal State Statistics Service of } \\
\text { Russian Federation (www.gks.ru) }\end{array}$ \\
\hline$I N C p c$ & $\begin{array}{l}\text { Per capita household income, } 2002 \text {, current prices, } \\
\text { roubles, }(3,541.750 ; 1,809.694)\end{array}$ & $\begin{array}{l}\text { Federal State Statistics Service of } \\
\text { Russian Federation (www.gks.ru) }\end{array}$ \\
\hline$P O P$ & $\begin{array}{l}\text { Regional population, 2002, thousand persons, } \\
(2,671.783 ; 1,852.006)\end{array}$ & $\begin{array}{l}\text { Federal State Statistics Service of } \\
\text { Russian Federation (www.gks.ru) }\end{array}$ \\
\hline Compete & $\begin{array}{l}\text { Regional enterprises per } 1000 \text { inhabitants, } 2002 \text {, } \\
(23.613 ; 12.770)\end{array}$ & $\begin{array}{l}\text { Federal State Statistics Service of } \\
\text { Russian Federation (www.gks.ru) }\end{array}$ \\
\hline GOVTemp & $\begin{array}{l}\text { Regional government employment, } 2002, \% \text { of } \\
\text { average annual employment in economy, }(1.952 ; \\
0.415)\end{array}$ & $\begin{array}{l}\text { Federal State Statistics Service of } \\
\text { Russian Federation (www.gks.ru) }\end{array}$ \\
\hline GOVTtran & $\begin{array}{l}\text { Transfers from the federal government per capita, } \\
2002 \text {, current prices, thousand roubles, (1.819; } \\
1.607)\end{array}$ & $\begin{array}{l}\text { Federal State Statistics Service of } \\
\text { Russian Federation (www.gks.ru) }\end{array}$ \\
\hline Privatize & $\begin{array}{l}\text { State enterprises privatized per } 1000 \text { inhabitants, } \\
2002,(0.021 ; 0.021)\end{array}$ & $\begin{array}{l}\text { Federal State Statistics Service of } \\
\text { Russian Federation (www.gks.ru) }\end{array}$ \\
\hline URBAN & $\begin{array}{l}\text { Regional urbanization rate, } 2002, \% \text {, } \\
(72.935 ; 10.669)\end{array}$ & $\begin{array}{l}\text { Federal State Statistics Service of } \\
\text { Russian Federation (www.gks.ru) }\end{array}$ \\
\hline$U N$ & $\begin{array}{l}\text { Regional unemployment rate, } 2002, \% \text {, } \\
(1.868 ; 0.873)\end{array}$ & $\begin{array}{l}\text { Federal State Statistics Service of } \\
\text { Russian Federation (www.gks.ru) }\end{array}$ \\
\hline DUMmspt & $\begin{array}{l}\text { A dummy variable that takes the value } 1 \text { if the } \\
\text { region is Moscow or St Petersburg }\end{array}$ & \\
\hline
\end{tabular}




\section{Table 2 Causes of Corruption Across Russian Regions}

\section{Panel A: Determinants of corruption perceptions}

Dependent Variable $=\log ($ CORRperc $)$

\begin{tabular}{|c|c|c|c|c|c|}
\hline & $\underline{1 \mathrm{~A}}$ & $\underline{\mathbf{2 A}}$ & $\underline{\mathbf{3 A}}$ & $\underline{\mathbf{4 A}}$ & $\underline{\mathbf{5 A}}$ \\
\hline GRPpc & $\begin{array}{l}-3.84 \mathrm{e}-06 * * \\
(5.4)\end{array}$ & & $\begin{array}{l}-4.06 \mathrm{e}-06^{* *} \\
(4.2)\end{array}$ & $\begin{array}{l}-4.10 \mathrm{e}-06^{* *} \\
(4.0)\end{array}$ & $\begin{array}{l}-3.55 \mathrm{e}-06^{* *} \\
(5.0)\end{array}$ \\
\hline$I N C p c$ & & $\begin{array}{l}-0.0001 * * \\
(3.9)\end{array}$ & & & \\
\hline$P O P$ & $\begin{array}{l}4.14 \mathrm{e}-06 \\
(0.1)\end{array}$ & $\begin{array}{l}-0.00006 \\
(0.9)\end{array}$ & & & \\
\hline $\mathrm{POP}^{2}$ & $\begin{array}{l}9.87 \mathrm{e}-09^{*} \\
(1.8)\end{array}$ & $\begin{array}{l}2.29 \mathrm{e}-08 * * \\
(3.9)\end{array}$ & & & \\
\hline Compete & & & $\begin{array}{l}0.04 * * \\
(2.8)\end{array}$ & $\begin{array}{l}0.04 * * \\
(2.4)\end{array}$ & $\begin{array}{l}0.03 * * \\
(2.9)\end{array}$ \\
\hline GOVTemp & & & $\begin{array}{l}-0.17 \\
(1.2)\end{array}$ & $\begin{array}{l}-0.20 \\
(1.1)\end{array}$ & \\
\hline GOVTtran & & & $\begin{array}{l}0.06 \\
(1.2)\end{array}$ & $\begin{array}{l}0.05 \\
(0.8)\end{array}$ & \\
\hline Privatize & & & & $\begin{array}{l}-0.26 \\
(0.1)\end{array}$ & \\
\hline URBAN & & & & & $\begin{array}{l}-0.01^{*} \\
(2.0)\end{array}$ \\
\hline$U N$ & & & & & $\begin{array}{l}-0.07 \\
(1.0)\end{array}$ \\
\hline DUMmspt & $\begin{array}{l}-0.43 * * \\
(5.4)\end{array}$ & $\begin{array}{l}-0.30 * * \\
(2.8)\end{array}$ & $\begin{array}{l}-1.74 * * \\
(2.8)\end{array}$ & $\begin{array}{l}-1.85^{* *} \\
(2.5)\end{array}$ & $\begin{array}{l}-1.31 * * \\
(2.4)\end{array}$ \\
\hline $\boldsymbol{R}^{2}$ & 0.20 & 0.25 & 0.28 & 0.29 & 0.33 \\
\hline $\begin{array}{l}\text { RESET } \\
(p-v a l u e)\end{array}$ & $\begin{array}{l}0.59 \\
(0.63)\end{array}$ & $\begin{array}{l}0.71 \\
(0.56)\end{array}$ & $\begin{array}{l}2.54^{*} \\
(0.08)\end{array}$ & $\begin{array}{l}2.69^{*} \\
(0.07)\end{array}$ & $\begin{array}{l}2.8^{*} \\
(0.06)\end{array}$ \\
\hline$N$ & 39 & 39 & 39 & 34 & 39 \\
\hline
\end{tabular}




\begin{tabular}{|c|c|c|c|c|c|}
\hline \multicolumn{6}{|c|}{$\begin{array}{l}\text { Panel B: Determinants of corruption incidence } \\
\text { Dependent Variable }=\log (\text { CORRamt })\end{array}$} \\
\hline & $\underline{1 B}$ & $\underline{2 B}$ & $\underline{3 B}$ & $\underline{4 B}$ & $\underline{5 B}$ \\
\hline GRPpc & $\begin{array}{l}-0.00001^{* *} \\
(6.2)\end{array}$ & & $\begin{array}{l}-0.00001 * * \\
(6.3)\end{array}$ & $\begin{array}{l}-0.00001 * * \\
(7.1)\end{array}$ & $\begin{array}{l}-0.00001^{* *} \\
(6.3)\end{array}$ \\
\hline$I N C p c$ & & $\begin{array}{l}-0.0004 * * \\
(5.2)\end{array}$ & & & \\
\hline$P O P$ & $\begin{array}{l}0.0002 \\
(1.2)\end{array}$ & $\begin{array}{l}0.00004 \\
(0.2)\end{array}$ & & & \\
\hline $\mathrm{POP}^{2}$ & $\begin{array}{l}3.11 \mathrm{e}-09 \\
(0.2)\end{array}$ & $\begin{array}{l}3.65 \mathrm{e}-08^{* *} \\
(2.8)\end{array}$ & & & \\
\hline Compete & & & $\begin{array}{l}0.008 \\
(0.4)\end{array}$ & $\begin{array}{l}0.005 \\
(0.2)\end{array}$ & $\begin{array}{l}0.01 \\
(0.7)\end{array}$ \\
\hline GOVTemp & & & $\begin{array}{l}0.01 \\
(0.03)\end{array}$ & $\begin{array}{l}-0.03 \\
(0.1)\end{array}$ & \\
\hline GOVTtran & & & $\begin{array}{l}-0.06 \\
(0.5)\end{array}$ & $\begin{array}{l}-0.07 \\
(0.5)\end{array}$ & \\
\hline Privatize & & & & $\begin{array}{l}-9.51 \\
(0.8)\end{array}$ & \\
\hline URBAN & & & & & $\begin{array}{l}-0.002 \\
(0.1)\end{array}$ \\
\hline$U N$ & & & & & $\begin{array}{l}-0.04 \\
(0.3)\end{array}$ \\
\hline DUMmspt & $\begin{array}{l}0.69 * * \\
(4.3)\end{array}$ & $\begin{array}{l}1.00 * * \\
(5.2)\end{array}$ & $\begin{array}{l}1.17 \\
(1.0)\end{array}$ & $\begin{array}{l}1.12 \\
(0.9)\end{array}$ & $\begin{array}{l}1.05 \\
(0.8)\end{array}$ \\
\hline$R^{2}$ & 0.34 & 0.33 & 0.25 & 0.28 & 0.24 \\
\hline $\begin{array}{l}\text { RESET } \\
\text { (p-value })\end{array}$ & $\begin{array}{l}1.34 \\
(0.28)\end{array}$ & $\begin{array}{l}0.60 \\
(0.62)\end{array}$ & $\begin{array}{l}1.2 \\
(0.34)\end{array}$ & $\begin{array}{l}0.91 \\
(0.45)\end{array}$ & $\begin{array}{l}0.81 \\
(0.50)\end{array}$ \\
\hline$N$ & 39 & 39 & 39 & 34 & 39 \\
\hline $\begin{array}{l}\text { Notes: See } 7 \\
\text { on robust st } \\
\text { and at the }\end{array}$ & $\begin{array}{l}\text { for variable } \\
\text { d errors. } * a \\
\text { el. }\end{array}$ & $\begin{array}{l}\text { nitions. Con } \\
\text { * respectivel }\end{array}$ & $\begin{array}{l}\text { ncluded but } \\
\text { ote denotes }\end{array}$ & $\begin{array}{l}\text { ported. Abs } \\
\text { tical signific }\end{array}$ & $\begin{array}{l}\text { t-statistics ba } \\
\text { at the } 10 \% \text { le }\end{array}$ \\
\hline
\end{tabular}




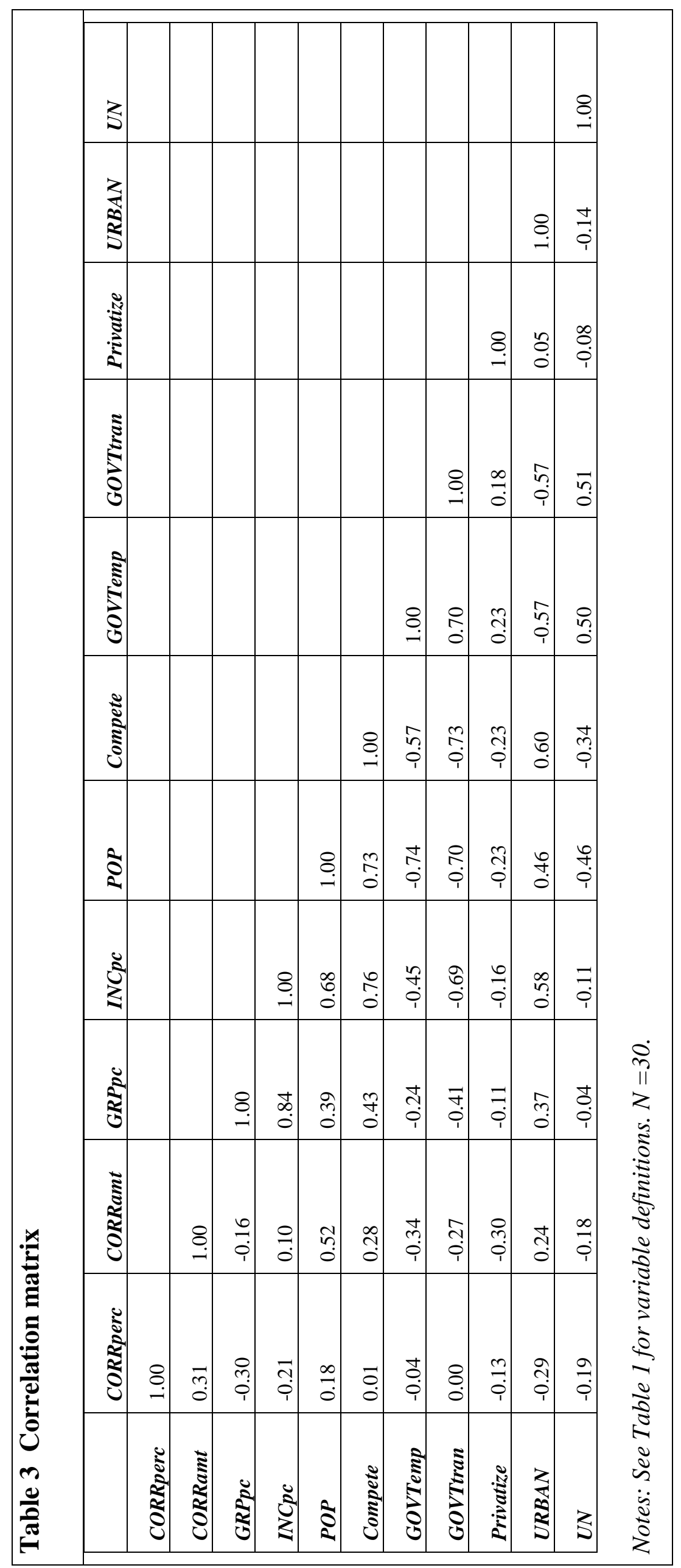




\begin{tabular}{|l|l|}
\hline $\begin{array}{l}\text { Appendix } \\
\text { List of regions in the sample }\end{array}$ \\
\hline Altai Krai & Primorski Krai \\
\hline Amur Oblast & Pskov Oblast \\
\hline Arkhangelsk Oblast & Rostov Oblast \\
\hline Bashkortostan & Ryazan Oblast \\
\hline Belgorod Oblast & Samara Oblast \\
\hline Chelyabinsk Oblast & Saratov Oblast \\
\hline Karelia & St.Petersburg \\
\hline Kemerovo Oblast & Stavropol Krai \\
\hline Khabarovsk Krai & Sverdlovsk Oblast \\
\hline Krasnodar Krai & Tambov Oblast \\
\hline Krasnoyarsk Krai & Tatarstan \\
\hline Kurgansk Oblast & Tomsk Oblast \\
\hline Leningrad Oblast & Tula Oblast \\
\hline Moscow & Tumen Oblast \\
\hline Moscow Oblast & Tver Oblast \\
\hline Nizhny Novgorod Oblast & Udmurtia \\
\hline Novgorod Oblast & Ulyanovsk Oblast \\
\hline Novosibirsk Oblast & Volgograd Oblast \\
\hline Omsk Oblast & Voronezh Oblast \\
\hline Perm Oblast & Yaroslavl Oblast \\
\hline Note: For details see Transparency International, Regional Corruption Indices 2002, \\
http://transparency.org.ru/proj_index.asp,
\end{tabular}

